Revue d'histoire de l'Amérique française

RAS REVUE D.HISTOIRE DE L'AMÉRIQUE FRANÇAISE

\title{
Réplique de René Marcel Sauvé au compte rendu de Jocelyn Létourneau du livre Le Québec, carrefour des empires
}

\section{René Marcel Sauvé}

Volume 61, numéro 2, automne 2007

URI : https://id.erudit.org/iderudit/018082ar

DOI : https://doi.org/10.7202/018082ar

Aller au sommaire du numéro

Éditeur(s)

Institut d'histoire de l'Amérique française

ISSN

0035-2357 (imprimé)

1492-1383 (numérique)

Découvrir la revue

Citer cet article

Sauvé, R. M. (2007). Réplique de René Marcel Sauvé au compte rendu de Jocelyn Létourneau du livre Le Québec, carrefour des empires. Revue d'histoire de l'Amérique française, 61(2), 340-340. https://doi.org/10.7202/018082ar d'utilisation que vous pouvez consulter en ligne. 


\section{Réplique au professeur Létourneau}

La RHAF a publié, à l'été 2007, une critique acerbe de mon dernier livre: Le Québec, carrefour des empires (Éditions du Québécois, 2007) sous la plume de Jocelyn Létourneau. Avec force arguments ad hominem, le professeur Létourneau "règle» mon cas «en trois mots» et condamne l'ouvrage.

D'abord, je ne suis pas un "ancien militaire qui se prend pour un nouveau philosophe», mais bien un géographe spécialisé en géopolitique et en polémologie, qui a fait 28 ans de carrière dans l'armée, notamment comme parachutiste, officier d'infanterie, officier d'État-major et professeur d'histoire militaire dans les écoles de guerre. Ma formation en histoire militaire m’a été donnée dans l'armée canadienne et chez les Britanniques. $\mathrm{Si}$, pour l'historien, l'histoire des guerres est un récit pragmatique, elle est pour le militaire l'histoire d'inqualifiables drames humains.

Le Québec, carrefour des empires n'est pas un texte historique au sens pragmatique voulu par les historiens. La géographie et la géopolitique ne sont pas des disciplines discursives, mais ontologiques. La possibilité de construire un État naturel est une proposition en devenir, dont la géopolitique cherche à saisir la trame. Les thèses se vérifient sur le terrain et par les cartes. Mon erreur aura donc sans doute été de ne pas avoir indiqué quelles cartes appuyaient les thèses contenues dans le texte.

Il existe présentement de nouvelles cartes produites par les photos satellites (dont la grande carte satellite du Québec préparée par mon collègue Léonce Naud) et qui offrent une vision multispectrale de la réalité géographique. Pour la géopolitique, l'histoire n'est pas une érudition construite autour de la vie de grands personnages, mais la conquête de statuts territoriaux par les peuples, les nations et les intérêts oligarchiques. De là l'importance des cartes. Un examen en profondeur de ces nouvelles cartes permet de tirer des conclusions inédites de certains événements historiques, dont les plus stratégiques concernent l'aménagement des communications. En fait, un tel examen démontre que les colons de la Nouvelle-France et leurs descendants n'ont jamais été des perdants.

Navré pour le professeur Létourneau. 